\title{
Publisher Correction: In vivo neutralization of dendrotoxin-mediated neurotoxicity of black mamba venom by oligoclonal human IgG antibodies
}

\author{
Andreas H. Laustsen (10 ${ }^{1}$, Aneesh Karatt-Vellatt (10 ${ }^{2}$, Edward W. Masters' ${ }^{2}$, Ana Silvia Arias (i) ${ }^{3}$,

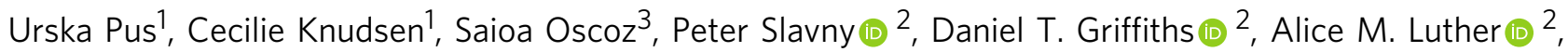 \\ Rachael A. Leah², Majken Lindholm (10) ${ }^{2}$, Bruno Lomonte (i) ${ }^{3}$, José María Gutiérrez ${ }^{3}$ \& John McCafferty (i) ${ }^{2}$
}

Correction to: Nature Communications https://doi.org/10.1038/s41467-018-06086-4; published online 2 October 2018

In the original version of this article, the sixth sentence of the first paragraph of the Introduction incorrectly read 'Particularly, elapid antivenoms often have an unbalanced antibody content with relatively low amounts of antibodies against small neurotoxic venom components that have low immunogenicity, which often leads to low immune cgqtns in production animals ${ }^{8-10}$ '. The correct version states 'responses' instead of 'cgqtns'. This has been corrected in both the PDF and HTML versions of the article.

Published online: 20 November 2018

\footnotetext{
(i) Open Access This article is licensed under a Creative Commons Attribution 4.0 International License, which permits use, sharing, adaptation, distribution and reproduction in any medium or format, as long as you give appropriate credit to the original author(s) and the source, provide a link to the Creative Commons license, and indicate if changes were made. The images or other third party material in this article are included in the article's Creative Commons license, unless indicated otherwise in a credit line to the material. If material is not included in the article's Creative Commons license and your intended use is not permitted by statutory regulation or exceeds the permitted use, you will need to obtain permission directly from the copyright holder. To view a copy of this license, visit http://creativecommons.org/licenses/by/4.0/.
}

(c) The Author(s) 2018

\footnotetext{
${ }^{1}$ Department of Biotechnology and Biomedicine, Technical University of Denmark, Søltofts Plads 224, DK-2800 Kongens Lyngby, Denmark. ${ }^{2}$ IONTAS Ltd., Iconix Park, London Road, Pampisford, Cambridgeshire CB22 3EG, United Kingdom. ${ }^{3}$ Instituto Clodomiro Picado, Facultad de Microbiología, Universidad de Costa Rica, San José 11501-2060, Costa Rica. Correspondence and requests for materials should be addressed to A.H.L. (email: ahola@bio.dtu.dk) or to A.K-V. (email: akv@iontas.co.uk) or to J.M.G. (email: jose.gutierrez@ucr.ac.cr)
} 